\title{
Technological properties of metallic-diamond tools manufactured by SPS process
}

\author{
Właściwości użytkowe narzędzi metaliczno-diamentowych \\ wytworzonych metodą SPS
}

\section{ELŻBIETA BĄCZEK*}

This paper presents the results of the technological properties of impregnated diamond tools fabricated via spark plasma sintering (SPS) during the process of grinding and cutting of highpurity oxides ceramics $\left(\mathrm{ZrO}_{2}\right)$ stabilized with $\mathrm{Y}_{2} \mathrm{O}_{3}$ or $\mathrm{MgO}$. As a metal matrix the water atomized tin bronze and steel-based matrix was used. After sintering, an analysis of microstructure was conducted using scanning electron microscopy. The resulting materials were tested for the apparent density determined by Archimedes' method, Rockwell hardness (scale B), Young's modulus, as well as for the technological properties. The performance results of obtained diamond composites were compared with commercial diamond wheel fabricated by HP (hot pressing), usually employed in the grinding of ceramics. Results showed that diamond tools based on Cu-Sn and steel, obtained by SPS, may be successfully used as a matrix in the impregnated diamond tools for cutting or grinding of high-purity oxides ceramics.

KEYWORDS: impregnated diamond tools, metal matrix composites, spark plasma sintering, hot pressing, grinding/cutting process, high-purity oxides ceramics

Przedstawiono wyniki badań właściwości fizycznych, mechanicznych i użytkowych narzędzi diamentowych wytworzonych metodą SPS (spark plasma sintering) w procesie szlifowania i cięcia półwyrobów z zaawansowanej ceramiki technicznej korundowej i cyrkonowej stabilizowanej tlenkiem itru $\left(\mathrm{Y}_{2} \mathrm{O}_{3}\right)$ lub magnezu (MgO). Jako materiał osnowy zastosowano rozpylany woda proszek brazu cynowego oraz stal stopowa. Wykazano, że materiały zaproponowane na osnowę zapewniają uzyskanie wysokich właściwości użytkowych narzędzi diamentowych otrzymanych metodą SPS w porównaniu z narzędziami diamentowymi otrzymanymi metodą prasowania na gorąco (HP).

SŁOWA KLUCZOWE: narzędzia metaliczno-diamentowe, metaliczna osnowa, spiekanie SPS, hot pressing, proces cięcia i szlifowania, zaawansowana ceramika techniczna

$\mathrm{ZrO}_{2}$ ceramics are among the oldest oxide-ceramic materials but were refined into a material with high performance properties fairly recently. Today, they are used for production of sophisticated materials with special electrical and mechanical properties. Due to their specific electrical, magnetic and thermal properties, modern ceramics

\footnotetext{
* Mgr inż. Elżbieta Bączek (elzbieta.baczek@ios.krakow.pl) - The Institute of Advanced Manufacturing Technology, Krakow
}

DOI: https://doi.org/10.17814/mechanik.2018.12.204

have also found their way into other applications. Depending on the main application, high-performance ceramics can be divided into functional ceramics (electrical or magnetic functions) and the so-called structural or engineering ceramics (mechanical function) [1]. These materials can be stabilized with $\mathrm{MgO}, \mathrm{Y}_{2} \mathrm{O}_{3}, \mathrm{CaO}$ and $\mathrm{CeO}_{2}$ [2].

For fast and low-loss manufacturing of parts from these materials, cutting diamond tools with high performance characteristics are required. Typical bonded abrasive tools include super hard grains (diamond or cubic boron nitride), filler (corundum, silicon carbide, boron nitride etc.), binder (sintered metal, electroplated, resin, ceramic, hybrid), modifiers (homogenizers, greases) and body (metal, ceramic, polymer). Currently, mainly synthetic diamond or cubic boron nitride grains are used [3]. A typical tool fabrication process utilizes various PM routes $[4,5]$.

For the consolidation of powder alloys, the most often used process consists of a cold pressing step followed by either free sintering in a reducing atmosphere or hot pressing in a graphite mould.

The spark plasma sintering (SPS) technique is a variant of the hot pressing technique (pressure-assisted sintering) which has the benefit of high heating rates, broad range of sintering temperature and short sintering time $[6,7]$. A typical SPS equipment is fitted with a vacuum chamber, wherein a graphite die is positioned and a hydraulic pressing system for the application of pressure. Initially, the diamond-metal powder mixture is uniaxially compacted inside the graphite die until the desired pressure is reached. Then the compressed powder is heated up to the sintering temperature by passing a high frequency pulsed current through the graphite die and, in the case of conductive materials, also through the powder sample.

During the current flow through the powder, a spark discharge occurs at the powder grain contact points, which removes adsorbed gases and oxides from the surface of the particles. Facilitates active contacts between sintered powder particles. At the moment of neck formation it is also possible Joule heating from this moment as the dominant driving force for the consolidation of materials (Fig. 1).

The aforementioned phenomena and very fast heating rates (up to $800 \mathrm{~K} \mathrm{~min}^{-1}$ ) make SPS viable for commercial use $[6,8]$. The SPS technique can be successfully used for synthesis and processing of ceramics, metals, cermets, intermetallics, etc. [9-12]. The pulsed current, which differentiates SPS technique from the conventional hot 


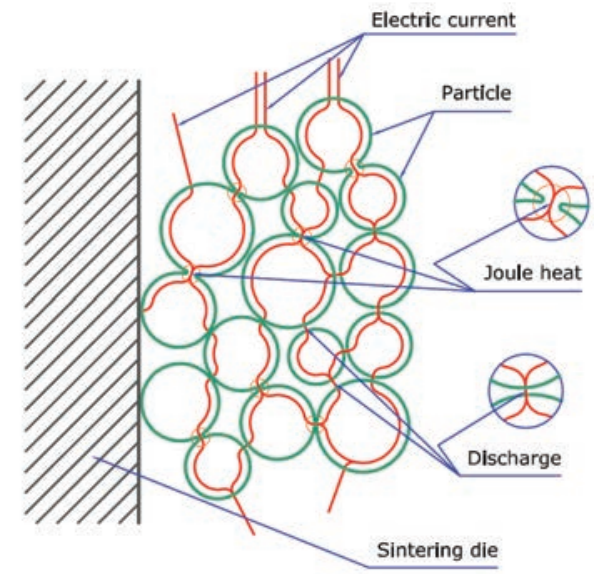

Fig. 1. Pulsed current flow through powder particles

pressing, has also been tested as an alternative method of heating in ultra high pressure synthesis of super hard materials [13-14]. It can also offer new ways for the manufacture of materials having properties tailored for special cutting or grinding tools.

$$
\text { ** } *
$$

This paper is dedicated to the study of the Cu-Sn and steel based system as bonding metallic matrix for use in impregnated diamond tools, fabricated by spark plasma sintering (SPS) process, used for grinding and cutting of zirconia ceramics stabilized with yttrium oxide or magnesium oxide.

\section{Materials and methods}

The water atomized tin bronze Cu-Sn (NAM40-80/20 grade $<38 \mu \mathrm{m}$, NeoChimie, France), steel-based matrix, containing Ni (Direct Steel 20, grade 5-20 $\mu \mathrm{m}$, EOS $\mathrm{GmbH}$, Germany) and synthetic diamond powder (APV, grade $105 \div 125 \mu \mathrm{m}$, Diambor C.T.H.) were used as starting materials (Fig. 2). The mixtures containing Cu-Sn +25 vol. $\%$ of diamond and Direct Steel $20+25$ vol. $\%$ of diamond were prepared using SpeedMixer DAC 400.1. The powders were mixed with rotation speed of $1000 \mathrm{rpm}$ for 30 min in acetone.

After mixing the powders were poured into a graphite mould and consolidated to near-full density using HP D125 SPS and HP D5 SPS type devices, produced by FCT Systeme, Germany (Fig. 3).

During SPS sintering the powder mixture was heated stepwise from room temperature to desired sintering
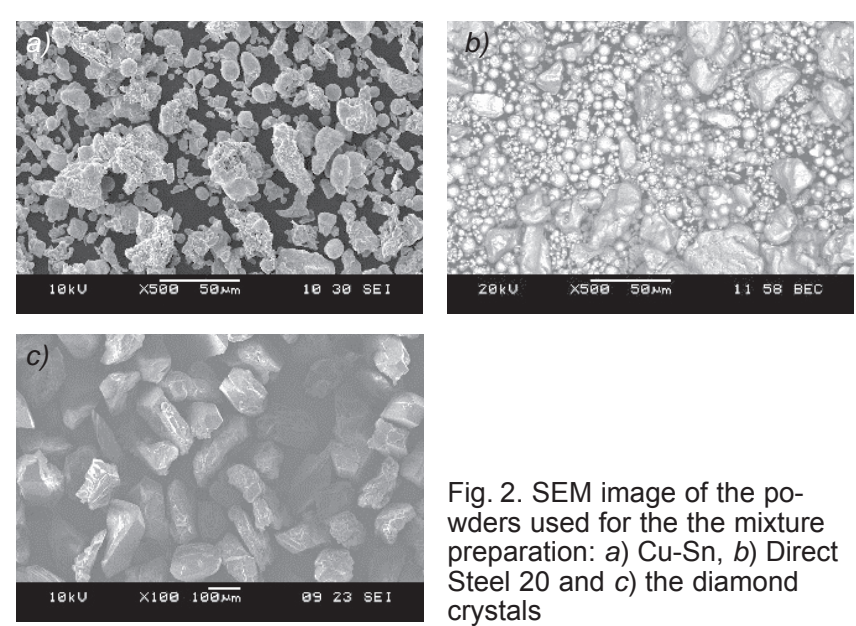

Fig. 2. SEM image of the powders used for the the mixture preparation: a) Cu-Sn, b) Direct Steel 20 and $c$ ) the diamond crystals
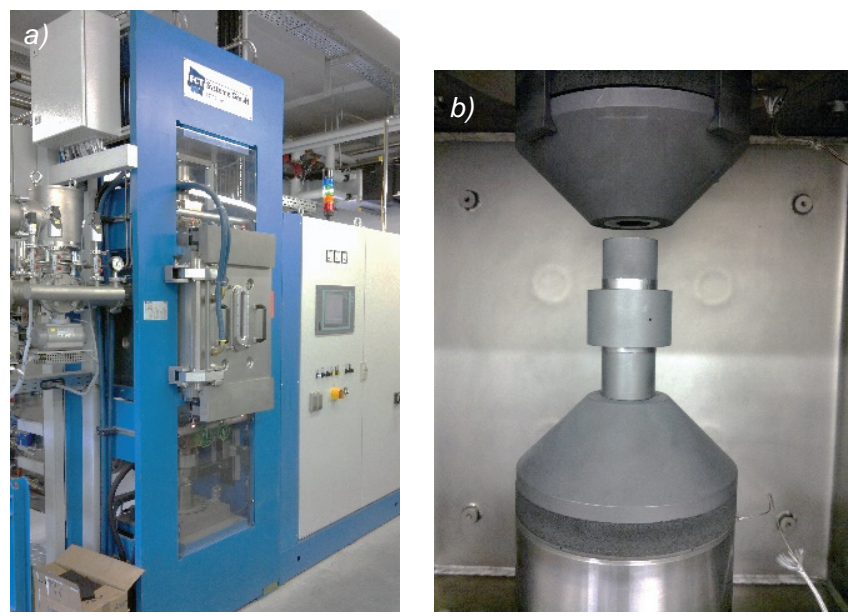

Fig. 3. Sintering furnance HP D125 SPS (a), sintering chamber with graphite elements $(b)$

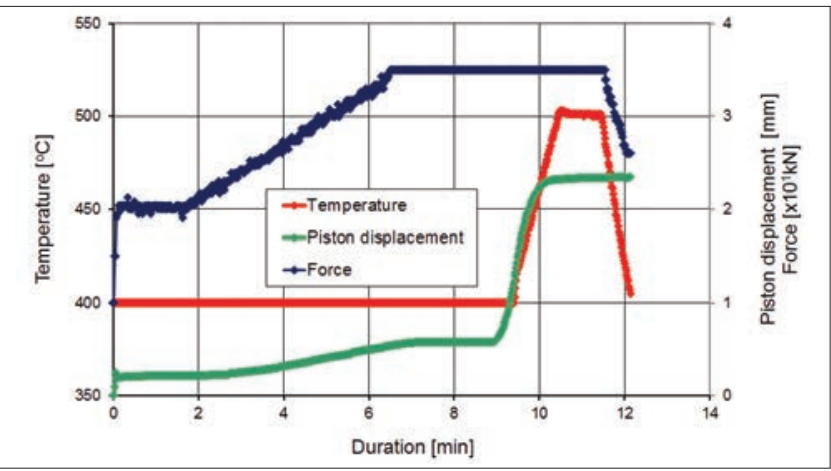

Fig. 4. Sintering SPS CuSn+D, 600C - 1 min (HP D125 FCT)

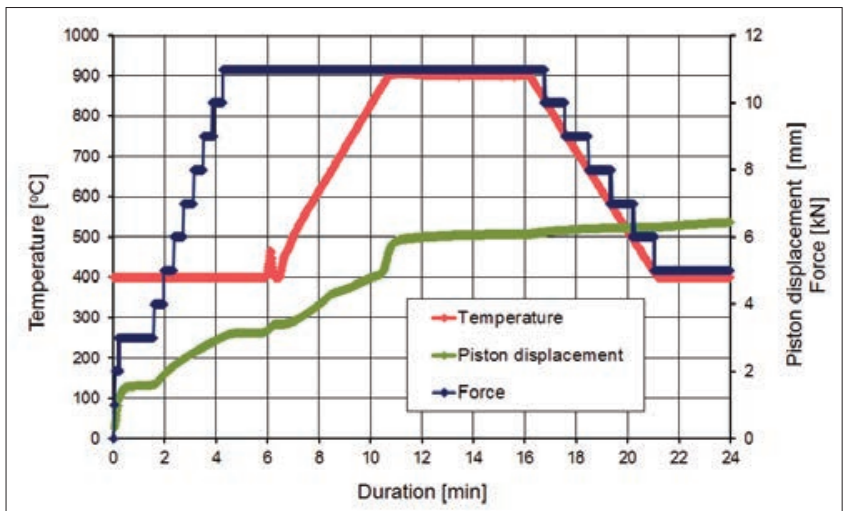

Fig. 5. Sintering SPS Direct Steel+D, 900C - 5 min (HP D5 FCT)

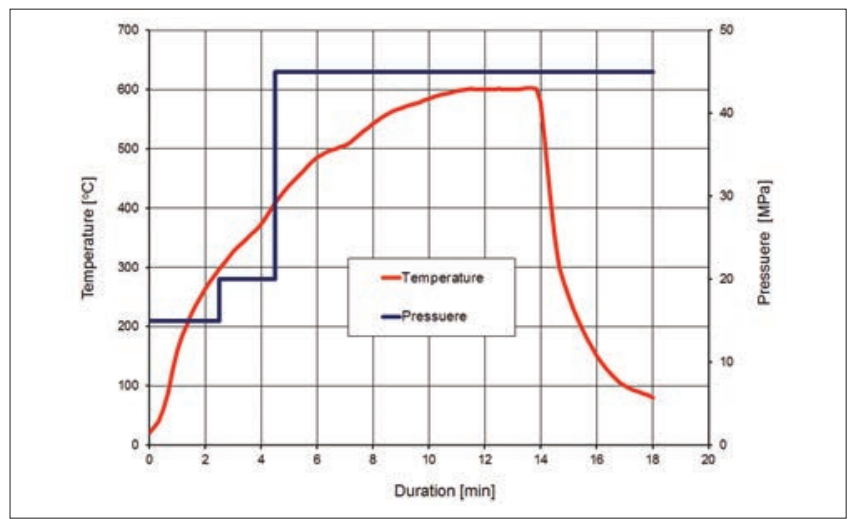

Fig. 6. Sintering HP CuSn+D, $600 \mathrm{C}-3 \mathrm{~min}$

temperature with a heating rate of $100 \mathrm{~K} \mathrm{~min}^{-1}$ in dynamic vacuum. A graphite sheet with $0.5 \mathrm{~mm}$ in thickness was inserted between the raw material powder and the 
graphite die to prevent punch scuffing and to lighten the sintered sample extraction from the matrix. The graphite die was also wrapped with carbon blankets in order to minimize the heat loss during the sintering process. Temperature measurement was done by a pyrometer. During the sintering process constant uniaxial compressive load was applied, heat was generated by passing pulsed DC current directly through the graphite die, as well as the powder compact. The powders were held at $550^{\circ} \mathrm{C}$ for 1 minute, under $16 \mathrm{MPa}$ (Cu-Sn +25 vol. $\%$ of diamond) or at $950^{\circ} \mathrm{C}$ for 10 minutes, under $35 \mathrm{MPa}$ (Direct Steel $20+25$ vol. \% of diamond) and subsequently cooled down to room temperature.

The resulting sintered metallic-diamond composites with diameter of $40 \mathrm{~mm}$ and a thickness of $3 \mathrm{~mm}$ (Fig. 7a) were used as blanks for further processing operations, i.e.: EDM drilling of a hole with a diameter of $\varnothing 14 \mathrm{~mm}$ (Fig. 7b); joining of steel frames with blanks (Fig. 7c) and a dressing (Fig. 7d).

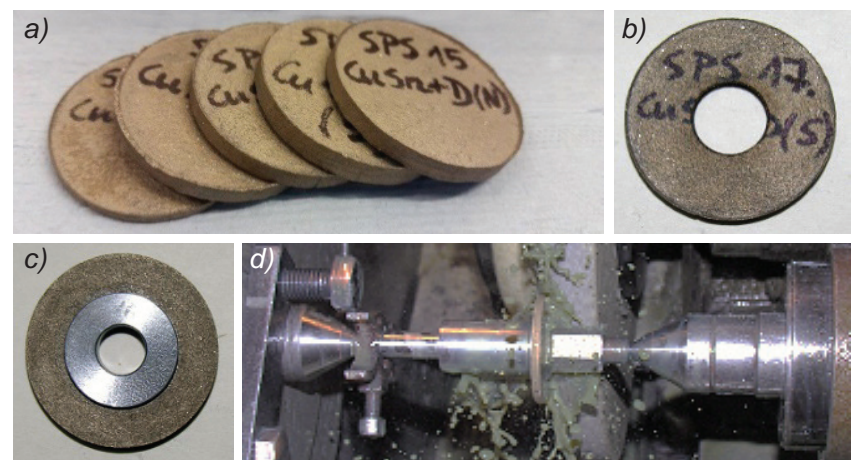

Fig. 7. Spark Plasma sintered metal-diamond composites based on Cu$\mathrm{Sn}$ system (a), the EDM drilled hole with a diameter of $\varnothing 14 \mathrm{~mm}(b)$, after joining of the steel frames with the blanks $(c)$ during the process of dressing $(d)$

The microstructure of the materials was studied with a scanning electron microscope (JEOL JSM-6460LV). Density of the sintered samples was measured by the Archimedes' method while their theoretical density was calculated applying the rule of mixtures and assuming densities of $8.96 \mathrm{~g} / \mathrm{cm}^{3}$ for Cu-Sn and $3.52 \mathrm{~g} / \mathrm{cm}^{3}$ for diamond.

Young's modulus of the composites was determined by ultrasonic method by measuring the velocity of ultrasonic waves passing through the material using an ultrasonic flaw detector (Panametrics Epoch III). The velocities of transversal and longitudinal waves were determined as a ratio of the sample thickness and the relevant transition time. The hardness was determined by the Rockwell method applying load of $980 \mathrm{~N}$ (100 KG).

Cutting and grinding tests were carried out on highperformance ceramics (FRIALIT ${ }^{\circledR}$-DEGUSSIT ${ }^{\circledR}$ provided by LABRO Technologie, Poland) stabilized with $\mathrm{MgO}$ and $\mathrm{Y}_{2} \mathrm{O}_{3}$, that is widely used in the energy, electronics, aerospace and automotive industries (Fig. 8). The cutting and grinding process were carried out on the modular grinding-electroerosion machine manufactured by IZTW and
Fig. 8. Samples of zirconia ceramics: a) DEGUSSIT FZY stabilized with yttrium oxide $\mathrm{Y}_{2} \mathrm{O}_{3}, b-c$ ) FRIALIT ${ }^{\circledR}$ FZM stabilized with magnesium oxide $\mathrm{MgO}$

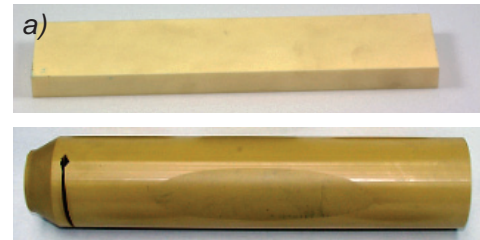

b)

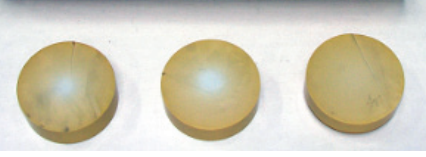

c)

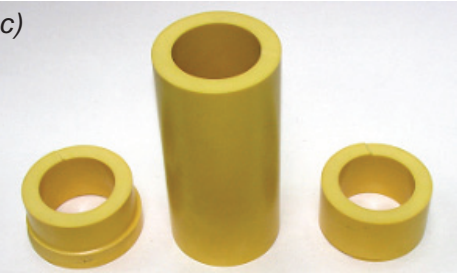

equipped with an attachment for a low grinding speed and cooling by means of spraying of a $2 \%$ PGA SYNKON solution in the coolant water.

The tests were carried out at constant peripheral speed of grinding wheel $V_{\mathrm{s}}=25 \mathrm{~m} / \mathrm{s}$, grinding depth (ap) of $3 \mathrm{~mm}$ (depth of the material layer of ground in one pass). The weight of the material removed $m$, the diameter of the wheel $D$ and the cutting time $t_{\mathrm{m}}$ were measured. The volume of removed material $V_{w}$, the material removal rate for the grinding/cutting, by volume, namely $Q_{w}$ and the material removal rate for the grinding/cutting, per unit of active grinding/cutting wheel $b_{\mathrm{c}}$, namely $Q^{\prime}{ }_{\mathrm{w}}$ and were calculated using the formulas below:

$$
\begin{aligned}
Q_{w} & =\frac{V_{w}}{t_{m}}\left[\frac{m}{s}\right] \\
Q^{\prime}{ }_{w} & =\frac{Q_{w}}{b_{c}}\left[\frac{m}{s}\right]
\end{aligned}
$$

The weight of the samples was measured before and after each cutting and grinding process with a laboratory scale with a measurement accuracy of up to $0.1 \mathrm{mg}$. The diameter of the wheel was measured using an electronic calipers with accuracy of up to $0.01 \mathrm{~mm}$.

\section{Results and discussion}

The results of measurement of density, hardness, and Young's modulus are shown in the table, whereas the fracture surface of a sintered diamond-impregnated specimens are presented in Fig. 9.

The space previously occupied by the diamond crystals are free of cracks, which proves good enough plasticity of the matrix material. During the sintering process, there is no chemical reaction between the diamond and matrix, as clearly illustrated in Fig. 9. The combination of diamond with a matrix is purely mechanical.

Examples of materials during the process of grinding and cutting are shown in Fig. 10 and the results of performance tests of the process of grinding and cutting are shown in Fig. 11

\begin{tabular}{|c|c|c|c|c|c|c|}
\hline \multirow{2}{*}{ Material - method } & \multicolumn{3}{|c|}{ Process conditions } & \multirow{2}{*}{$\begin{array}{l}\text { Density, } \\
\mathrm{g} / \mathrm{cm}^{3}\end{array}$} & \multirow{2}{*}{ HRB } & \multirow{2}{*}{$\begin{array}{c}\text { Young's modulus, } \\
\text { GPa }\end{array}$} \\
\hline & Temperature, ${ }^{\circ} \mathrm{C}$ & Time, $\min$ & Pressure, $\mathrm{MPa}$ & & & \\
\hline Cu-Sn +25 vol. $\%$ of diamond - SPS & 500 & 1 & 16 & $7.40 \pm 0.01$ & $102 \pm 1.64$ & 189 \\
\hline Direct Steel $20+25$ vol. $\%$ of diamond - SPS & 900 & 5 & 35 & $6.78 \pm 0.01$ & $104 \pm 4$ & 187 \\
\hline $\mathrm{Cu}-\mathrm{Sn}+25$ vol. $\%$ of diamond $-\mathrm{HP}$ & 600 & 3 & 45 & $7,57 \pm 0.01$ & $103 \pm 1.64$ & 186 \\
\hline
\end{tabular}

TABLE. Sintering parameters and properties of $\mathrm{Cu}-\mathrm{Sn}$ and Direct Steel matrix materials with diamond additives 

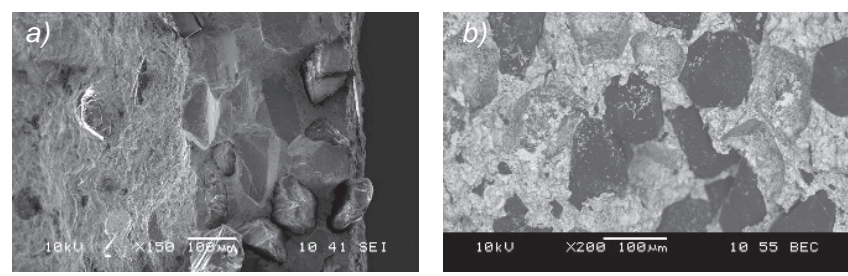

Fig. 9. Fracture surface of a spark plasma sintered diamond-impregnated specimens with diamond pull-out pits: a) Cu-Sn +20 vol. $\%$ of diamond sintered at $550{ }^{\circ} \mathrm{C}$ for 1 minute under $16 \mathrm{MPa}, b$ ) Direct Steel $20+25$ vol. $\%$ of diamond sintered at $900{ }^{\circ} \mathrm{C}$ for 10 minutes under $35 \mathrm{MPa}$
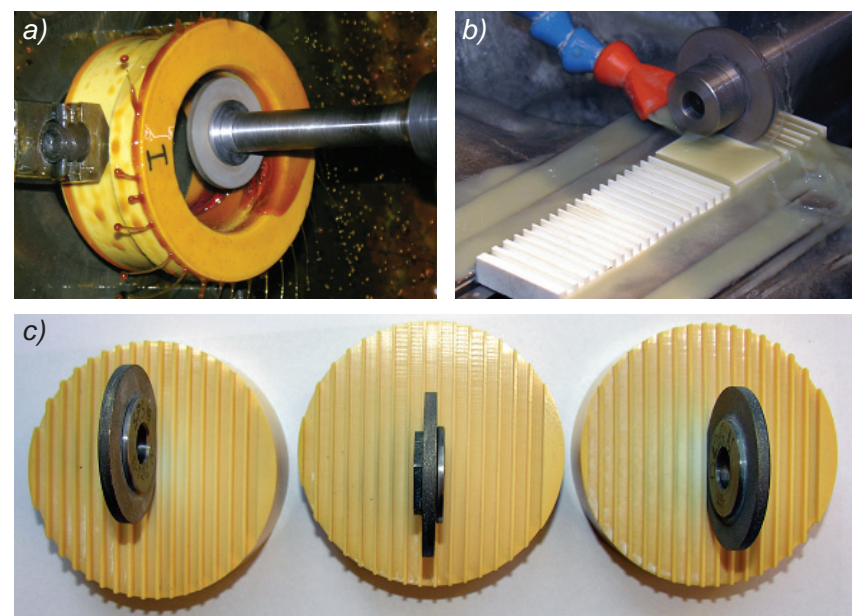

Fig. 10. The process of: a) grinding the internal surface of cylindrical rings with zirconia ceramics FRIALIT ${ }^{\circledR}$ FZM stabilized with $\mathrm{MgO}$; the process of cutting of the samples: $b$ ) the zirconia ceramics DEGUSSIT ${ }^{\circledR}$ FZY stabilized with $\mathrm{Y}_{2} \mathrm{O}_{3}$ and c) FRIALIT ${ }^{\circledR}$ FZM stabilized with $\mathrm{MgO}$

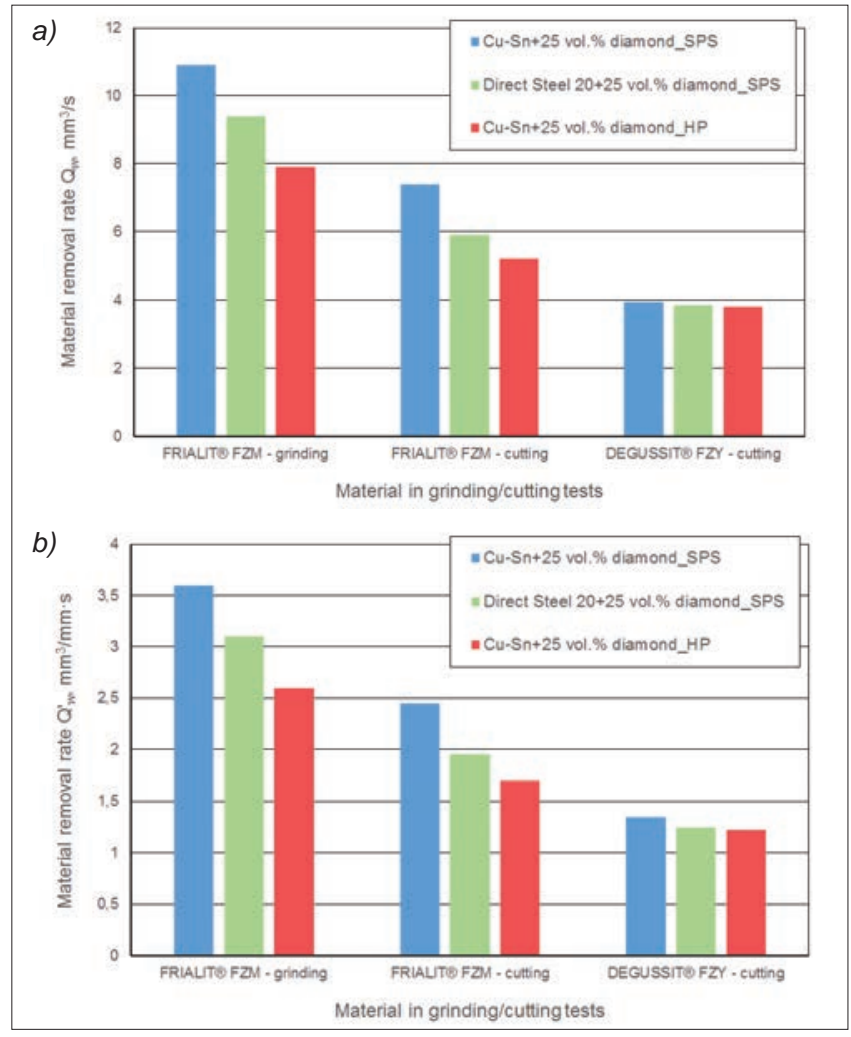

Fig. 11. Results of grinding and cutting of high-purity oxides ceramics $\left(\mathrm{ZrO}_{2}\right)$ stabilized with $\mathrm{Y}_{2} \mathrm{O}_{3}$ or $\mathrm{MgO}:$ a) material removal rate, $\left.b\right)$ material removal rate per unit active grinding wheel width

Research assessment of the suitability of the diamond tools for grinding or cutting of high-purity oxides ceramics $\left(\mathrm{ZrO}_{2}\right)$ stabilized with $\mathrm{Y}_{2} \mathrm{O}_{3}$ or $\mathrm{MgO}$ showed that the highest productivity of grinding or cutting was achieved for the wheel received by SPS. In all three cases, there was no tool wear during laboratory testing. The highest performance for grinding and cutting was noted for the wheel withe the composition of $\mathrm{Cu}-\mathrm{Sn}+25$ vol. $\%$ of diamond received by SPS (Fig. 7). During the grinding of zirconia ceramics DEGUSSIT ${ }^{\circledR}$ FZY stabilized with yttrium oxide $\mathrm{Y}_{2} \mathrm{O}_{3}$ all the diamond tools work in a similar way. Significant differences were recorded for cutting zirconia ceramics FRIALIT ${ }^{\circledR}$ FZM stabilized with magnesium oxide MgO.

\section{Conclusions}

It can be stated that:

- The investigated powders were consolidated to the closed porosity condition by SPS method.

- Application of spark plasma sintering method (SPS) allows for obtaining of material with higher performance properties at low sintering temperature $\left(200 \div 500^{\circ} \mathrm{C}\right)$ and in a much shorter time compared to the commonly used method (hot pressing).

- All the tests indicate that the use of the Cu-Sn and steel based system as metal matrix is very promising.

- The SPS device makes it possible sintering metallic-diamond tools for grinding and cutting of ceramics composites. The use of this method is an entirely new and promising direction.

This work was supported by the statutory activity of the Institute of Advanced Manufacturing Technology, Krakow, Poland, and by the project: SINTERCER FP7-REGPOT-2012-2013-1 „Development of a sintering center and know-how exchange for non equilibrium sintering methods of advanced ceramic composite materials".

\section{REFERENCES}

1. Reckziegel A. "Technical paper properties and applications of high-performance ceramics made of zirconia". Mannheim Revision, FRIATEC AG, 2015; http://www.friatec-ceramics.com/images/fa-properties-zirconia.pdf.

2. Smuk B., Szutkowska M., Walter J. "Alumina ceramics with partially stabilized zirconia for cutting tools". Journal of Materials Processing Technology. 133 (2003): pp. 195-198.

3. Staniewicz-Brudnik B., Bacczek E. Skrabalak G. "The new generation of diamond wheels with vitrified (ceramic) bonds". Sintering Techniques of Materials. Thandalam, Chennai, India: INTECH. Arunachalam Lakshmanan Saveetha Engineering College, 2015, pp. 53-76.

4. Konstanty J. "Powder metallurgy diamond tools". Metal Powders Technology. Oxford: Elsevier, 2005.

5. Konstanty J. "Cobalt as a Matrix in Diamond Impregnated Tools for Stone Sawing Applications". Krakow: AGH University of Science and Technology, 2002.

6. Tillmann W., Kronholz C., Ferreira M., Knote A., Theisen W., Schütte P. "Comparison of different metal matrix systems for diamond tools fabricated by new current induced short-time sintering processes". PM2010 World Congr. - Diam. Tools. Manuscr. Ref. by Dr José M Sanchez. Spain: CEIT, 2010.

7. Schmidt J., Knote A., Armbrüster M., Weißgärber Th. "Spark plasma sintering of diamond impregnated wire saw beads". Diam. Appl. Technol. 64 (2011): pp. 35-40.

8. Handtrack D., Despang F., Kieback B., Reinfried N., Grin Y. "Fabrication of ultra-fine grained and dispersion-strengthened titanium materials by spark plasma sintering". Mater. Sci. Eng. 437 (2006): pp. 423-429.

9. Schmidt J., Weißgärber Th., Schubert T. "Spark plasma sintering of intermetallics and metal matrix composites". Euro PM2005 Sinter. II (2005).

10. Zhou X., Wang Y., Li T., Li X., et. al. "Fabrication of diamond-SiC-TiC composite by a spark plasma sintering-reactive synthesis method". J. Eur. Ceram. Soc. 35 (2015): pp. 69-76.

11. Luo C., Qi Y., Pan C., Yang W. "Diamond synthesis from carbon nanofibers at low temperature and low pressure". Nat. Publ. Gr. 2015: pp. 1-6.

12. Grasso S., Hu Ch., Maizza G., Sakka Y. "Spark plasma sintering of diamond binderless WC composites”. J. Am. Ceram. Soc. 95 (2012): pp. 2423-2428.

13. Yunga D.L., Cygan S., Antonova M., Jaworska L., Hussinova I. "Ultra high-pressure spark plasma sintered ZrC-Mo and ZrC-TiC composites". Int. J. Refract. Metals Hard Mater. 16 (2016): pp. 201-206.

14. Knaislova A., Novak P., Cygan S., Jaworska L., Cabibbo M. "High-pressure spark plasma sintering (HP SPS): A promising and reliable method for preparing Ti-Al-Si Alloys". Materials. 10, 5 (2017): pp. 6-13. 